\title{
A Lab Scale Study on the Effects of Waste Lubricating Oil to Red Tilapia Oreochromis sp. Juveniles
}

\author{
RUHANA HASSAN*1, SA’ADIAH SALIM ${ }^{1}$, NURUL JANNAH ISMAIL ${ }^{2} \&$ ABDUL \\ RAZAK ISMAIL ${ }^{2}$ \\ ${ }^{1}$ Department of Aquatic Science, Faculty of Resource Science and Technology, Universiti Malaysia \\ Sarawak, 94300 Kota Samarahan, Sarawak; ${ }^{2}$ Faculty of Petroleum and Renewable Energy \\ Engineering, Universiti Teknologi Malaysia, 81310 Skudai, Johor
}

\begin{abstract}
Waste lubricating oil is defined as used lubricating oil removed from internal combustion engines. Among the sources of this chemical are vehicles, mining, agricultural, industrial and construction equipment. Rapid industrialisation, urbanisation and increase in volume of transportation have increased environmental risks to aquatic organisms and human health for example improper disposal of waste lubricating oil into environment has affect human via bioaccumulation and biomagnification processes, besides direct impact on the aquatic ecosystem. A lab scale study was conducted to determine the effect of waste lubricating oil on red tilapia Oreochromis sp. juveniles. In this toxicity test, Oreochromis sp. juveniles were reared in a static system and subjected to four different concentrations of waste lubricating oil $(50 \mathrm{ml} / \mathrm{L}, 90 \mathrm{ml} / \mathrm{L}, 120 \mathrm{ml} / \mathrm{L}$ and $200 \mathrm{ml} / \mathrm{L})$ and observed for 96 hours. The lethal concentration, $\mathrm{LC}_{50}$ of waste lubricating oil in this study was $91.20 \mathrm{ml} / \mathrm{L}$. There was a significant difference in the effects of waste lubricating oil on the mortality rate of Oreochromis sp. among treatments. Mortality of fish has strong positive correlation with concentration of waste lubricating oil added to the tanks. Swimming performances of test fish were reduced after 24 hours exposure to waste oil lubricants concentrations of 120 and $200 \mathrm{ml} / \mathrm{L}$. Severe inflammation was observed on the kidney tissues of exposed fish after 96 hours experiment. Overall, water temperature and dissolved oxygen values recorded during toxicity test were constant and within the range for optimum values culturing tilapias. However mean $\mathrm{pH}$ value decreased from 7.19 to 5.33 as the concentrations of waste lubricating oil increased. This study only involved Oreochromis sp. juveniles as test fish; in future, study should also include other fish species. Findings reported here is limited to lab scale study, therefore the actual effects of waste lubricating oil deposited in the wild ecosystem is still unknown and need further investigations.
\end{abstract}

Keywords: waste lubricating oil, Oreochromis sp., behaviour, $\mathrm{LC}_{50}$

\section{INTRODUCTION}

Waste lubricating oil or waste engine oil is usually used lubricant oil discharge from engine parts of land vehicle such as cars, motorcycles, buses and trucks and marine transportation like ships, boats, as well as aircrafts. Lubricant oil is widely used to lubricate engine parts (John \& David, 2009) and has been used extensively in the equipment and machines in agricultural, industrial and mining industries. Their functions are to clean, improve sealing, prevent corrosion, and cool the engine by removing the heat. Waste lubricating oil has a finite lifetime, thus it needs to be changed regularly to protect the engine.

*Corresponding author:hruhana@frst.unimas.my
Large amount of waste lubricating oil is discharged daily into the terrestrial and aquatic ecosystems due to maintenance activities (Faizul et al., 2012). This liquid is brown to black in colour; and as a result from the uncontrolled release of the waste into drainage channels and canals (Ayoola et al., 2012), waste lubricating oil could be found in almost all aquatic bodies. Malaysia is gradually shifting from agriculture to large-scale factorybased industry country. Urbanisation is expanding rapidly, in line with the national agenda to become a fully-developed nation by the year 2020. Both industrialization and urbanisation have environmental risks and sustainable management of natural resources has 
become more challenging. About 150 million litres of waste lubricating oil is produced annually in Malaysia due to active transportation goods by ships and land transport as well as increase in traffic volume (Faizul et al., 2012). Oil spill into the ocean from ships (Khan \& Singh, 2011) is inevitable, either due to accidents or deliberate disposal of the oil, because Straits of Malacca is a major commercial shipping route between Indian Ocean and Pacific Ocean. The expansion of world trade had further triggered higher traffic volume that causes uncontrolled vessels discharges such as de-ballasting, tank cleaning, bilging and bunkering (Maizatun \& Mariani, 2011).

The Department of Environment, Malaysia stated that waste oil is classified as scheduled wastes under the First Schedule of the Environmental Quality (Schedule Wastes) Regulations 2005. However, since the enforcement of this law is lacking, waste lubricating oil pollution problem remains unresolved. Some studies about the waste lubricating oil spill had been carried out in Malaysia, for example, Faizul et al. (2012) had designed the Intelligent $\mathrm{SoC}$ Controller for engine oil sensing and monitoring system but how far this new invention had benefited the nation remains unclear.

Tilapia has been cultured since the ancient Egyptian days, and it remains as a major freshwater species to be cultured worldwide (Lim \& Webster, 2006). In Malaysia, Red Nile Tilapia (Oreochromis sp.) contributes approximately $90 \%$ of the total tilapia production (Amal \& Zamri, 2011). Tilapia is a hardy species and resistant to unfavourable water quality compared to other freshwater fish. It has the ability to tolerate low dissolved oxygen concentration, wide range of salinity and high levels of ammonia. Due to these characteristics, tilapia has become one of the most preferred test organisms in toxicity test (Newman \& Unger, 2003). In this study, tilapia juveniles had been chosen as test organism, as juveniles are more sensitive to environmental changes compared to adults. Other factors considered were the cost involved, availability of the fish and lab facilities as well as the level of skill needed to handle the test fish throughout the acclimatisation stage and the toxicity test period.

\section{MATERIALS \& METHODS}

Juveniles of red tilapia, Oreochromis sp. with average total length of $5.5 \pm 0.2 \mathrm{~cm}$ were used in this experiment. All test fish were obtained from Fisheries Research Institute Gelang Patah, Johor. Waste lubricating oil (mixed types) was obtained from workshops in Johor Bahru area. A total of 200 juveniles of Oreochromis sp. were acclimatised at the Drilling Laboratory, Faculty of Petroleum, Universiti Teknologi Malaysia for six days prior to the toxicity test experiment. All test fish were placed in a big container comprising $100 \mathrm{~L}$ of de-chlorinated tap water following Thongra-ar et al. (2003). The acclimatisation stage was conducted at ambient temperature $\left(28-30^{\circ} \mathrm{C}\right)$ with photoperiod of 12 hours light 12 hours dark and dissolved oxygen concentration (DO) was maintained between $60-100 \%$ saturation using the aeration system. Juveniles were fed ad libitum with commercial pellets twice a day during this acclimatisation stage.

Table 1. Description of treatments that were used in toxicity test.

\begin{tabular}{ccc}
\hline Tank no. & Treatment & Concentration of waste lubricating oil $(\mathbf{m l} / \mathbf{L})$ \\
\hline 1-Mar & A & 50 \\
4-Jun & B & 90 \\
7-Sep & C & 120 \\
10-Dec & D & 200 \\
13-15 & Control & No oil added \\
\hline
\end{tabular}


For toxicity experiment, 120 juveniles of Oreochromis sp. were exposed to four different concentrations $(50 \mathrm{ml} / \mathrm{L}, 90 \mathrm{ml} / \mathrm{L}, 120 \mathrm{ml} / \mathrm{L}$ and $200 \mathrm{ml} / \mathrm{L}$ ) of waste lubricating oil in a static system supplied with aeration (total volume of $2 \mathrm{~L}$ per tank with eight fish per tank and run for 96 hours) inclusive of one control experiment (Table 1). All treatments were carried out in triplicates. The experiment involved: i) documenting the mortality of test fish at every 24 hours, (ii) observing changes in fish behaviour at 24 hours interval and (iii) examining changes in kidneys of test fish after 96 hours exposure to waste lubricating oil. The fish juveniles were considered dead as they remain immobile and sink on the bottom of the tank (Rodrigues et al., 2010). Selected ambient water quality parameter monitoring was also involved during this experiment on daily basis; water temperature, $\mathrm{pH}$ and dissolved oxygen (DO) were measured using Hanna HI9810 and Hanna HI9142 instrument.

The kidneys of the dead test fish were dissected and preserved in 10\% buffered formalin (Ayoola \& Alajabo, 2012). With aid of compound microscope Nikon Eclipse 80i, any changes in test fish kidney between the control and the treatments were examined and recorded.

$\mathrm{LC}_{50}$ value of toxicity test was analysed using Probit analysis. One-way ANOVA and Tukey Test (if necessary) were used to determine whether there are any differences in terms of number of fish mortality and water quality between treatment (Ling \& Hong, 2012) using software SPSS ver 16. In addition,
Pearson Correlation analysis and Linear Regression were also performed using SPSS ver 16.

\section{RESULTS}

After 96 hours, Treatment D showed the highest percentage of fish mortality $(100 \%)$ followed by Treatment C (79\%), and Treatment B $(46 \%)$ whereas Treatment A showed the lowest mortality rate $(8 \%)$ (Table 2). One-way ANOVA showed significant difference in the mean of mortality between all treatments $(\mathrm{P}=0.001, \alpha=0.05)$.

Number of mortality of Oreochromis sp. juveniles is significantly correlated with concentration of waste lubricating oil in the experiment $\quad(\mathrm{P}=0.001 ; \quad \mathrm{r}=0.957) . \quad$ Linear Regression analysis showed strong positive correlation between concentrations of waste lubricating oil with percentage of Oreochromis sp. juveniles mortality (Linear $\mathrm{R}^{2}=0.916$ ) indicating that the more concentrate the waste lubricating oil added into the water, the rate of mortality of the juvenile fish becomes higher.

Mortality vs $\log _{10}$ concentration of waste lubricating oil is presented in Figure 1. After calculation using antilog formula, Median Lethal Concentration that caused $50 \%$ of mortality $\left(\mathrm{LC}_{50}\right)$ is $91.20 \mathrm{ml} / \mathrm{L}$.

Selected ambient in situ water quality parameters were recorded during the experiments (Table 3 ). The highest mean water temperature was $28.6^{\circ} \mathrm{C}$ (Treatment A and Control) whereas the lowest mean water

Table 2. Fish mortality for each treatment and replicate.

\begin{tabular}{ccccccc}
\hline Treatment & $\begin{array}{c}\text { Waste } \\
\text { lubricant } \\
\text { concentration } \\
\text { (ml/L) }\end{array}$ & R1 & R2 & R3 & $\begin{array}{c}\text { Total } \\
\text { mortality }\end{array}$ & $\begin{array}{c}\text { Percentage of } \\
\text { mortality }\end{array}$ \\
\hline A & 50 & 0 & 1 & 1 & 2 & 8 \\
B & 90 & 4 & 4 & 3 & 11 & 46 \\
C & 120 & 6 & 6 & 7 & 19 & 19 \\
D & 200 & 8 & 8 & 8 & 24 & 100 \\
Control & No oil added & 0 & 0 & 0 & 0 & 0 \\
\hline
\end{tabular}




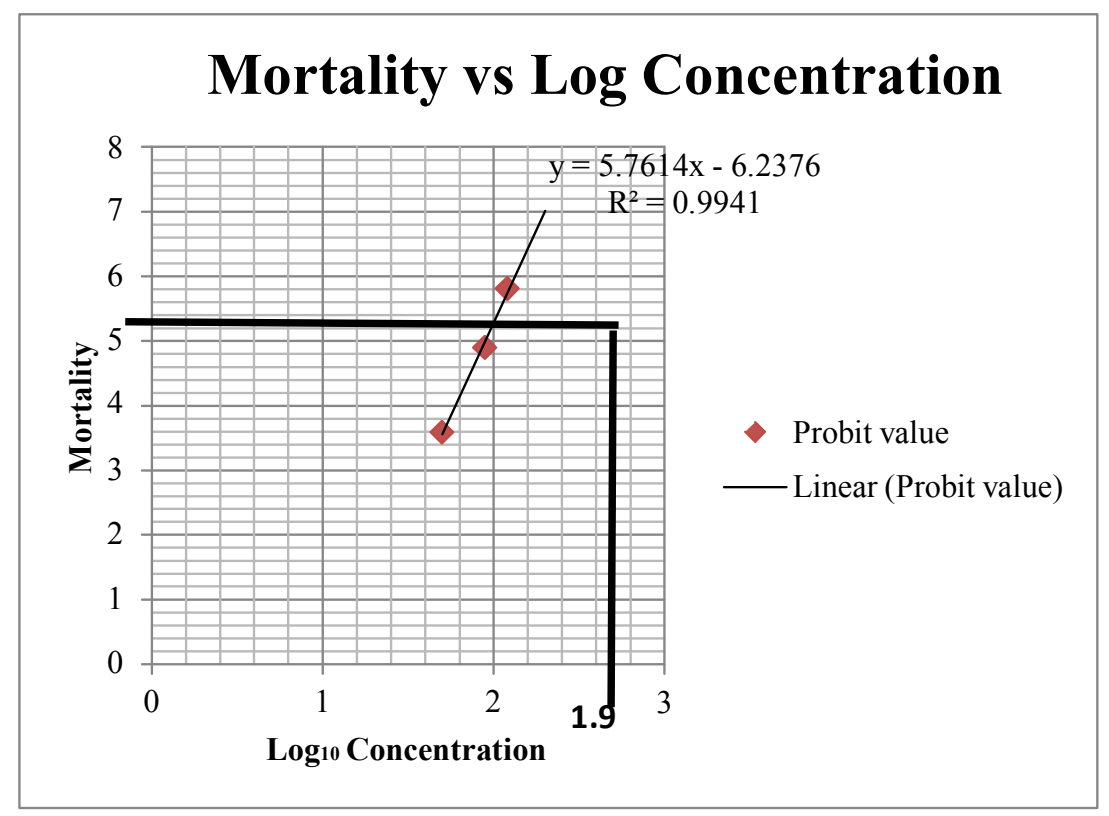

Figure 1. Mortality vs $\log _{10}$ Concentration.

temperature was $28.53^{\circ} \mathrm{C}$ in Treatment C. For DO, Treatment B and D recorded the lowest value $(7.43 \mathrm{mg} / \mathrm{L})$ whereas the highest value of DO was found in Treatment A $(7.45 \mathrm{mg} / \mathrm{L})$. In this experiment, a wide range of $\mathrm{pH}$ values were recorded among treatments; Treatment D recorded $\mathrm{pH} 5.33$ while Control showed $\mathrm{pH}$ 7.19. Statistical analysis one-way ANOVA showed significant difference in mean of $\mathrm{pH}$ between all treatments $(\mathrm{P}=0.001, \alpha=0.05)$. Pearson Correlation analysis showed that the number of Oreochromis sp. juveniles mortality is significantly correlated with $\mathrm{pH}$ value $(\mathrm{P}=$ $0.001 ; \mathrm{r}=-0.955)$, suggesting that juvenile fish mortality will increase as $\mathrm{pH}$ values become much lower than the $\mathrm{pH}$ in the control experiment.

Behavioural changes of test fish are summarised in Table 4. At the end of the experiment, for Treatment A, two out of eight fish were dead, whereas the other six individuals showed erratic swimming. For Treatment B, four out of eight test fish were dead whereas the other four showed erratic swimming behaviour. For Treatment $\mathrm{C}$, six out of eight fish were dead whereas the other two individual fish were floated ventral side up. For Treatment D, during our 48 hours observation, all fish were dead. For Control, all fish were actively swimming throughout the
96 hour of the experiment. In treatment $C$ and $D$, all test fish showed erratic swimming behaviour on the $24^{\text {th }}$ hours exposure, before death. For treatment A, fish showed erratic swimming on the $96^{\text {th }}$ hours observation and similar behaviour could be seen in treatment B during $48^{\text {th }}$ hours observation. Six fish in Treatment $\mathrm{C}$ lost their equilibrium and floated ventral side up at the $72^{\text {nd }}$ hours.

The kidneys from Control fish showed healthy red colour (natural) whereas the kidneys of test fish were brownish-black in colour. Other than that, on the kidneys of test fish, we observed dark spots marking the inflammation of cytoplasms.

\section{DISCUSSION}

During this study, the percentage of fish mortality, Oreochromis sp. juveniles has been increased from $8 \%$ to $100 \%$ with the increase in concentration of waste lubricating oil (50 $\mathrm{ml} / \mathrm{L}$ to $200 \mathrm{ml} / \mathrm{L}$ ). Similarly, Ayoola and Alajabo (2012) reported that the mortality of Black Jaw Tilapia, Sarotherodon melanotheron was increased from $2 \%$ to $98 \%$ with the increase in concentration of waste lubricating oil (5 to $40 \mathrm{ml} / \mathrm{L}$ ) and time of exposure (24 hours to 96 hours). In addition, Ayoola et al. 
Table 3. Temperature, DO and $\mathrm{pH}$ values recorded during 96 hours toxicity test.

\begin{tabular}{cccccc}
\hline Parameter & A & B & C & D & Control \\
\hline Temperature $\left({ }^{\circ} \mathrm{C}\right)$ & $28.60 \pm 0.00$ & $28.59 \pm 0.01$ & $28.53 \pm 0.01$ & $28.59 \pm 0.00$ & $28.60 \pm 0.00$ \\
DO $(\mathrm{mg} / \mathrm{L})$ & $7.45 \pm 0.01$ & $7.43 \pm 0.01$ & $7.44 \pm 0.01$ & $7.43 \pm 0.01$ & $7.44 \pm 0.01$ \\
$\mathrm{pH}$ & $6.77 \pm 0.02$ & $5.81 \pm 0.01$ & $5.70 \pm 0.01$ & $5.33 \pm 0.01$ & $7.19 \pm 0.01$ \\
\hline
\end{tabular}

(2012) stated that the mortality of African catfish, Clarias gariepinus increased from 10\% to $100 \%$ with the concentration of waste lubricating oil (100 to $400 \mathrm{ml} / \mathrm{L})$. After 96 hours of the experiment, no mortality of test fish had occurred in the Control, where no waste lubricant oil was added. Total mortality (100\% mortality) was recorded in $200 \mathrm{ml} / \mathrm{L}$ of waste lubricating oil, 79\% mortality of test fish was recorded in $120 \mathrm{ml} / \mathrm{L}$ of waste lubricating oil, followed by $46 \%$ mortality in $90 \mathrm{ml} / \mathrm{L}$ of waste lubricating oil and $8 \%$ mortality in 50 $\mathrm{ml} / \mathrm{L}$ of waste lubricating oil on the 96 hours of the experiment. In another study, Ayoola et al. (2012) who worked on the lethal effect of waste lubricating oil on adult fish, $C$. gariepinus, reported that $100 \%$ mortality of test fish was recorded in $800 \mathrm{ml} / \mathrm{L}$ of waste lubricating oil, followed by $89 \%$ mortality in $600 \mathrm{ml} / \mathrm{L}$ of waste lubricating oil and $44.33 \%$ mortality in $400 \mathrm{ml} / \mathrm{L}$ of waste lubricating oil. Different concentrations of lubricating oil needed to cause $100 \%$ mortality between the two studies may be due to different species and size of the test fish used. Oreochromis sp. juveniles fish (total length: $5.5 \pm 0.02 \mathrm{~cm}$ ) were used in this experiment while adult $C$. gariepinus fish (total length: $8.0 \pm 0.2 \mathrm{~cm}$ ) were used by Ayoola et al. (2012). Reports had confirmed that juvenile fish is more sensitive to toxicant compared to adult fish (Ugwu et al., 2011).

Erratic swimming behaviour and loss of equilibrium could easily be seen particularly when the concentration of waste lubricating oil is high. In general, addition of waste lubricating oil into the water will lower the $\mathrm{pH}$ of the water. Low $\mathrm{pH}$ could promote stress to the fish and they may die if the $\mathrm{pH}$ drops below 5.0 (Sloman et al., 2006). Ayoola and Alajabo (2012) also reported that $S$. melanotheron showed erratic swimming after exposed to lubricating oil, lost their equilibrium, remain immobile and eventually dead. In contrast, Ugwu et al. (2011) reported C. gariepinus fingerlings showed slow swimming performance after 24 hours exposure to oil pollutant, however they also noted that prolong exposure to oil pollutant had resulted in death. Abnormal swimming behaviour was caused by lack of efficiency in nervous system and muscular coordination due to accumulation of harmful toxic from oil pollutant in neuromuscular junctions and synaptic.

In this study, the waste lubricating oil concentration that caused $50 \%$ mortality of the test fish $\left(\mathrm{LC}_{50}\right)$ was $91.20 \mathrm{ml} / \mathrm{L}$. Other studies reported different $\mathrm{LC}_{50}$ values, for example, the $\mathrm{LC}_{50}$ value on the effect of lubricating oil on black jaw tilapia, $S$. melanotheron was recorded to be $13.18 \mathrm{ml} / \mathrm{L}$ (Ayoola \& Alajabo, 2012) whereas $562 \mathrm{ml} / \mathrm{L}$ for acute toxicity of waste lubricating oil on C. gariepinus (Ayoola et al., 2012). The different values obtained perhaps are due to species and size of test fish as well as types of lubricating oil used in the experiments.

The mean water temperatures in all treatments ranged between 28.53 to $28.6^{\circ} \mathrm{C}$. These values were considered as suitable temperature for Oreochromis sp. juveniles to survive. According to Elnady et al. (2010), the optimum water temperature range for most fish species is $24-30^{\circ} \mathrm{C}$. In addition, juvenile fish prefer warmer water temperature than adult fish (Sigurd et al., 2008).

Aeration system was provided to all treatments during the toxicity test. The mean of DO values recorded in this study ranged between 7.43 to $7.45 \mathrm{mg} / \mathrm{L}$, which is considered as optimum range values for rearing Oreochromis sp. juvenile (Lim \& Webster, 2006). In addition, Mohammed and Amal 
Table 4. Behavioural responses of fish during the 96 hours experiment.

\begin{tabular}{lcl}
\hline Treatment & Hour & Behavioural response \\
& 0 & The experiment began with 8 fish per tank. \\
A $(50 \mathrm{ml} / \mathrm{L})$ & 24 & All fish were actively swimming. \\
& 48 & All fish were actively swimming. \\
& 72 & All fish were actively swimming. \\
& 96 & 2 fish died, others showed erratic swimming. \\
& 0 & The experiment began with 8 fish per tank \\
B $(90 \mathrm{ml} / \mathrm{L})$ & 48 & All fish were actively swimming. \\
& 72 & All fish showed erratic swimming behaviour. \\
& 96 & 4 fish died, the other 5 fish showed erratic swimming behaviour. \\
& 0 & The experiment began with 8 fish per tank. \\
& 24 & All fish showed erratic swimming behaviour. \\
& 48 & 2 fish died, the other 6 fish lost their equilibrium. \\
C $(120 \mathrm{ml} / \mathrm{L})$ & 72 & 5 fish died, the other 3 fish lost their equilibrium. \\
& 96 & 6 fish died and the other 2 fish floated ventral side up. \\
& 0 & The experiment began with 8 fish per tank. \\
& 24 & All test fish showed erratic swimming. \\
& 48 & All test fish died. \\
D $(200 \mathrm{ml} / \mathrm{L})$ & 72 & - \\
& 96 & - \\
\hline Control & $0-96$ & All 8 individual test fish were actively swimming. \\
\hline
\end{tabular}

(2009) reported that suitable DO range for optimum growth rate of tilapia is 7 to $8.3 \mathrm{mg} / \mathrm{L}$. Huge differences in $\mathrm{pH}$ values had been recorded during this study, for example Control has mean $\mathrm{pH}$ of 7.19 whereas treatment $\mathrm{D}$ has mean $\mathrm{pH}$ 5.33. Similarly, Ayoola and Alajabo (2012) reported that the $\mathrm{pH}$ of water decreased from 7.5 to 3.7 with the addition of $400 \mathrm{ml}$ of lubricating oil into the experiment tank. Other than that, studies also showed waste lubricating oil could decrease $\mathrm{pH}$ values of soil (Agbogidi, 2010) which later influence the success of crop plantations (Njoku et al., 2012).

Harmful impurities containing acidic compounds were produced and accumulated during lubricating oil application in combustion engines (Emam \& Abeer, 2012). The concentration of Polycyclic Aromatic Hydrocarbon (PAHs) in lubricating oil increased with the time of usage (Sharifi et al., 2007). Due to oxidation process and thermal degradation during its usage in the internal combustion engines, a lot of impurities were formed in waste lubricating oil. These impurities contain dirt and metal parts that worn out from the engine parts. Waste metals from internal engines such as iron, lead, cadmium, chromium and other contaminants like water, dust and various impurities are absorbed and distributed into the various tissues of organism such as liver and kidney (Moura et al., 2010). At the end of toxicity test, we found that the kidneys from Control fish showed natural red colour whereas the kidney from exposed test fish were brownishblack in colour. In addition, inflammatory cytoplasms were observed in kidney tissues of the exposed test fish, while no significant change could be observed in Control fish kidneys. Ayoola and Alajabo (2012) had reported that the lubricating oil had effects on the gill, kidney and muscle of the juvenile of black jaw tilapia, $S$. melanotheron. They also reported the severe congestion and inflammation in the kidney tissues of the test fish.

\section{CONCLUSION}

$\mathrm{LC}_{50}$ value of waste lubricating oil in this study was $91.20 \mathrm{ml} / \mathrm{L}$. Mortality of juvenile tilapia fish showed strong positive correlation with the concentration of waste lubricating oil added into the tanks. Changes in swimming performances of test fish could be observed after 24 hours exposure to waste oil lubricants 
with concentration of 120 and $200 \mathrm{ml} / \mathrm{L}$. Severe inflammation of the kidney tissues of exposed fish after 96 hours experiment was also recorded in this study. The findings reported in this manuscript is limited to laboratory scale study, hence the actual effects of waste lubricating oil deposited in the wild aquatic ecosystem is still debatable and need further investigations.

\section{ACKNOWLEDGEMENT}

We would like to thank Prof. Dr. Lee Nyanti (UNIMAS) for his kind donation of fish juveniles used during trial experiments in October 2012 and to Fisheries Research Institute Gelang Patah, Johor for providing fish juveniles during this toxicity test. We would like to acknowledge contributions of staff and students from both UNIMAS and UTM, for their help and support during this study. Thank you to mechanics from various workshops in Kota Samarahan and Johor Baharu for allowing us to sample their waste oil lubricants. Thank you to UNIMAS and UTM for providing equipment and facilities used as well as some allocation from Belanjawan Mengurus Fakulti 2011/2012 to purchase chemicals and consumables used in this small project.

\section{REFERENCES}

Agbogidi, O.M. (2010). Response of six cultivars of cowpea [Vigna unguiculata (L.)Walp] to spent engine oil. African Journal of Food Science and Technology, 1 (6):139-142.

Amal, M.N.A. \& Zamri, S.M. (2011). Streptococcosis in tilapia (Oreochromis niloticus). Pertanika Journal of Tropical Agriculture, 34(2):195-206.

Ayoola, S.O. \& Alajabo, O.T. (2012). Acute toxicity and hispathological effects of engine oil on Black Jaw Tilapia, Sarotherodon melanotheron. AmericanEurasian Journal of Toxicological Sciences, 4(1):48-55.

Ayoola, S.O., Oluwatoyin, S., \& Akaeze, C.O. (2012). Genotoxic evaluation and toxicity of spent engine oil on Clarias gariepinus. Research Journal of Environmental Toxicology, 6:133-141.
Elnady, M.A., Alkobaby, A.I., Salem, M.A., Mohamed, A.S., \& Asran, B.M. (2010). Effect of fertilization and low quality feed on water quality dynamics and growth performance of Nile tilapia (Oreochromis niloticus). Journal of American Science, 6(10):1044-1054.

Emam, E.A. \& Abeer, M.S. (2012). Refining of used lubricating oil, by solvent/clay and acid/clay-percolation processes. Journal of Science and Technology, 2(11):1034-1041.

Faizul, I., Sawal, H.A., \& Shabiul, I. (2012). Design of intelligent SoC controller for engine oil sensing and monitoring system. Asian Journal of Scientific Research, 5(3):70-77.

John, C.S. \& David, O.C. (2009). The generation, use and disposal of waste crankcase oil in developing countries: A case for Kampla District, Uganda. Journal of Hazardous Material, 161(3): 835-841.

Khan, J.A. \& Singh, S. (2011). Evaluation of oil degradation potential of Micrococcus varians. International Journal of Applied Biology and Pharmaceutical Technology, 2(4):75-80.

Lim, C.E. \& Webster, C.D. (eds) (2006). Tilapia: biology, culture and nutrition. New York: Food Product Press.

Ling, T.Y. \& Hong, K.S. (2012). Elementary statistics for sciences with SPSS. Kota Samarahan, Malaysia: Universiti Malaysia Sarawak.

Maizatun, M. \& Mariani, A. (2011). Protection of marine biodiversity from pollution: Legal strategies in Malaysia. International Journal of Bioscience, Biochemistry and Bioinformatics, 1(4):276-281.

Mohammed, S.E. \& Amal, M.I. (2009). Performance of Nile Tilapia (Oreochromis niloticus) fingerlings II: influence of different water temperatures. International Journal of Agriculture and Biology, 11(3):301-309.

Moura, L.G.M., Assuncao, F.J.L., \& Ramos, A.C.S. (2010). Recovery of used lubricant oils through adsorption of residues on solid surfaces. Brazilian Journal of Petroleum and Gas, 4(3):91-102. 
Newman, M.C. \& Unger, M.A. (2003). Fundamentals of ecotoxicology ( $\left.2^{\text {nd }} \mathrm{Ed}\right)$. Boca Raton, FL: Lewis Publishers.

Njoku, K.L., Modupe, O.A., \& Temitope, O.B. (2012). Effect of time of application of spent oil on the growth and performance of maize (Zea mays). African Journal of Environmental Science and Technology, 6(1):67-71.

Rodrigues, R.V., Miranda-Filho, K.C., Gusmao, E.P., Moreira, C.B., Romano, L.A., \& Sampaio, S.A. (2010). Deleterious effects of water-soluble fraction of petroleum, diesel, and gasoline on marine pejerrey Odontesthes argentinensis larvae. Science of the Total Environment, 408:2054-2059.

Sharifi, M., Sadeghi, Y. \& Akarpour, M. (2007). Germination and growth of six plant species on contaminated soil with spent oil. International Journal of Environmental Science and Technology, 4(4):463-470.
Sloman, K.A., Wilson, R.W., \& Balshine, S. (2006). Behaviour and physiology of fish. San Diego, California: Elsevier Academic Press.

Sigurd, O.H., Albert, K.I. \& Sigurd, O.S. (2008). The effect of temperature and fish size on growth, feed intake, food conversation efficiency and stomach evacuation rate of Atlantic Salmon postsmolts. Journal of Aquaculture, 21:36-42.

Thongra-ar, W., Parkpian, P., \& Tang, A. (2003). Toxicity of mercury to growth and survival of seabass larvae, Lates calcarifer and the modifying effects of salinity. Research Article in Science Asia, 29:209219.

Ugwu, L.L.C., Ude E.F., Nwamba, H.O. \& Chima, I.N. (2011). Effect of crude oil and some petroleum products on Clarias gariepinus fingerlings (catfish: Claridae). Continental Journal of Fisheries and Aquatic Science, 5(1):24-30. 